DOI: $10.11649 / a .2227$

Article No.: 2227

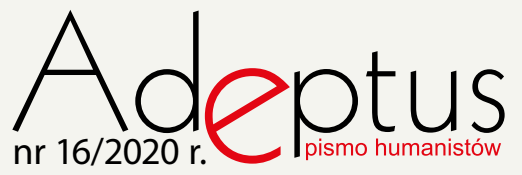

Magdalena Gapsa - slawistka i językoznawczyni. Absolwentka Wydziału Filologicznego Uniwersytetu Łódzkiego (studia licencjackie i magisterskie na kierunku filologia słowiańska). Od roku 2019 doktorantka i młoda badaczka w Katedrze Przekładoznawstwa Wydziału Filozoficznego Uniwersytetu w Lublanie. W swoich badaniach zajmuje się leksykografią komputerową, szczególną uwagę poświęca synonimii w słoweńskich i polskich słownikach, leksykonach i tezaurusach internetowych.

ORCID: https://orcid.org/0000-0003-2763-4495

e-mail: Magdalena.Gapsa@ff.uni-lj.si

Magdalena Gapsa

\title{
Słowniki w dobie digitalizacji na przykładzie Słownika wyrazów bliskoznacznych współczesnego języka słoweńskiego (Slovar sopomenk sodobne slovenščine)
}

\section{Wstęp}

W dobie rewolucji cyfrowej coraz trudniej jest wyobrazić sobie życie bez osiągnięć techniki. Jedną z korzyści płynących z jej rozwoju jest niewątpliwie bezpłatne udostępnianie w Internecie zasobów językowych, w tym także słowników, co leksykografom umożliwia szybsze reagowanie na zachodzące w języku zmiany, a użytkownikom słowników łatwiejszy i szybszy dostęp do interesujących ich informacji. Jak we wstępie do publikacji Using Online Dictionaries zauważa niemiecka specjalistka w dziedzinie leksykografii komputerowej Carolin Müller-Spitzer, „wielu ekspertów jest zdania, że słowniki internetowe są słownikami przyszłości"1 (Müller-Spitzer, 2014, s. 4), nie dziwi zatem fakt, że w dzisiejszych czasach powstaje coraz więcej słowników elektronicznych i innych zasobów językowych, które udostępniane są w sieci.

Proces ten na szeroką skalę objął także słowniki języka słoweńskiego. W słoweńskiej leksykografii można wyraźnie zaobserwować dwie tendencje. Pierwszą z nich jest cyfryzacja

\footnotetext{
1 Jeśli nie zaznaczono inaczej, tłumaczenia pochodzą od Autorki artykułu.
} 
słowników istniejących wcześniej jedynie w wersji tradycyjnej, co dotyczy głównie słowników starszych. W przypadku opracowań nowszych (czyli powstających komputerowo) obejmuje ona publikację słowników najpierw w wersji tradycyjnej, a następnie udostępnienie ich także w wersji elektronicznej. Druga tendencja to publikacja zasobów mających z założenia powstawać i funkcjonować jedynie w wersji elektronicznej (tzw. urodzonych cyfrowo, ang. digital born). Jednym z pierwszych tego typu zasobów językowych dla języka słoweńskiego jest udostępniony w roku 2018 Słownik ${ }^{2}$ wyrazów bliskoznacznych współczesnego języka słoweńskiego (słń. Slovar sopomenk sodobne slovenščine, SSSS).

Celem niniejszego artykułu jest przedstawienie wspomnianego słownika, na którego przykładzie staram się przybliżyć również polskiemu środowisku leksykograficznemu nowe rozwiązania w dziedzinie leksykografii komputerowej. W kolejnych częściach opisuję koncepcję słownika, przyczyny jego powstania i proces jego tworzenia oraz nowy typ słownika - słownik reagujący, którego pierwszym przykładem jest właśnie Słownik wyrazów bliskoznacznych współczesnego języka słoweńskiego. Próbuję pokazać, że istnieją sposoby skrócenia i obniżenia kosztów prac nad przygotowywaniem słowników, które w wielu aspektach zostały sprawdzone podczas redagowania SSSS. Jedną z głównych kwestii, rodzących wiele pytań, jest włączenie użytkowników w proces tworzenia słowników, co także może zostać odpowiednio skomentowane na przykładzie SSSS. Omawiam także wady i zalety prezentowanych rozwiązań.

\section{Elektroniczne słowniki języka słoweńskiego}

Współczesna leksykografia słoweńska ${ }^{3}$ jest niejako zmonopolizowana przez Instytut Języka Słoweńskiego im. Frana Ramovša Słoweńskiej Akademii Nauki i Sztuki. Swoje słowniki Instytut początkowo wydawał jedynie w wersji papierowej. W roku 2000 słoweński językoznawca i informatyk Primož Jakopin zainicjował rozwój portalu Zbiory słownikowe i tekstowe (słń. Slovarske in besedilne zbirke, Inštitut za slovenski jezik, 2018), gdzie zaczęto publikować

\footnotetext{
${ }^{2}$ Za nazwę wyjściową uznaję tytuł słoweński, zatem opisywane źródło nazywane będzie słownikiem, chociaż oficjalna nazwa angielska zawiera słowo thesaurus, czyli pol. tezaurus (por. Center za jezikovne vire in tehnologije, b.d.-a).

${ }^{3}$ Na potrzeby artykułu za początek współczesnej leksykografii słoweńskiej uznaję rok 1970, czyli rok wydania pierwszego tomu Słownika słoweńskiego języka literackiego (słń. Slovar slovenskega knjižnega jezika), który jest "niewątpliwie największym osiągnięciem leksykografii słoweńskiej” (Ostromęcka-Frączak, 2007, s. 95) oraz "dotychczas najobszerniejszym i najbardziej wyczerpującym słownikowym opracowaniem leksyki języka słoweńskiego" (Ostromęcka-Frączak, 2007, s. 104), choć jak zaznacza słoweńska językoznawczyni i leksykografka Ada Vidovič Muha o początkach współczesnej leksykografii słoweńskiej i nowoczesnym spojrzeniu na nią można mówić od połowy XIX wieku, od czasów słoweńskiego slawisty i filologa Franca Miklošiča, którego teorię i poglądy na temat słownika języka słoweńskiego wcielił w życie dopiero słoweński językoznawca i leksykograf Maks Pleteršnik w Słowniku słoweńsko-niemieckim (1894-1895) (Ostromęcka-Frączak, 2007, s. 97; Vidovič Muha, 2013, s. 11).
} 
także zdigitalizowane wersje słowników opracowanych i wydanych przez Instytut Języka Słoweńskiego. Portal ten stał się prototypem dla udostępnionego 14 października 2014 portalu Fran (Inštitut za slovenski jezik, 2020). Obecnie użytkownicy korzystają z siódmej wersji portalu Fran, która została zaktualizowana 3 grudnia 2019 roku. Oferuje on dostęp do 39 słowników, atlasu lingwistycznego oraz dwóch poradni językowych. Większość źródeł jest jednak cyfrową wersją wydanych wcześniej przez Instytut słowników5 ${ }^{5}$ Umożliwia to oczywiście szybsze i przede wszystkim bezpłatne ich użytkowanie, należy jednak mieć świadomość, że niektóre z haseł zostały opracowane 50 lat temu i nie były aktualizowane wraz z naturalnym rozwojem języka. Na portalu dostępne są także dwa słowniki urodzone cyfrowo, tzw. słowniki rosnące (słń. rastoči slovar) - ukazujący się od roku 2014 Bieżący słownikjęzyka słoweńskiego (słń. Sprotni slovar slovenskega jezika) oraz ukazujący się od roku 2016 elektroniczny Słownik słoweńskiego języka literackiego, czyli eSSKJ, które łącznie oferują ok. 2500 haseł.

Odmienne spojrzenie na digitalne zasoby językowe prezentuje Centrum Zasobów i Technologii Językowych Uniwersytetu w Lublanie (Center za jezikovne vire in tehnologije Univerze v Ljubljani, CJVT UL). Pierwszą ważną publikacją CJVT było udostępnienie w roku 2018 Słownika wyrazów bliskoznacznych współczesnego języka słoweńskiego (słń. Slovar sopomenk sodobne slovenščine, SSSS). Wpływ na jego powstanie miały przede wszystkim dwa czynniki - do roku 2016, kiedy to Instytut Języka Słoweńskiego wydał papierową wersję Słownika synonimów języka słoweńskiego (słń. Sinonimni slovar slovenskega jezika, SSSJ), nie istniało żadne opracowanie słoweńskiej synonimii, a wydany słownik (SSSJ) już w momencie publikacji był nieaktualny, gdyż prace nad nim trwały 15 lat (projekt słownika przygotowano w roku 2001, zob. Snoj, 2019, ss. 263-273), a powstawał w głównej mierze na podstawie materiałów z SSKJ (1970-1991) (Krek i in., 2017, s. 93).

Zasoby językowe opracowywane przez CJVT, w tym SSSS, z założenia mają być zasobami przeznaczonymi do użytku internetowego (Čibej, 2019, s. 1) czy też urodzonymi cyfrowo, nie są

\footnotetext{
${ }^{4}$ Data nie jest przypadkowa - 3 grudnia w Słowenii obchodzony jest Ta veseli dan kulture, nieformalne święto ustanowione w roku 2000 na pamiątkę narodzin France Prešerna (1800-1849), uznawanego za najwybitniejszego słoweńskiego poetę. Tego dnia instytucje kulturowe i akademickie (dzień jest także rocznicą pierwszego wykładu na Uniwersytecie w Lublanie) organizują dni otwarte oraz wykłady gościnne. Co roku tego dnia aktualizowany jest także portal Fran.

${ }^{5}$ Np. digitalizacja Słownika słoweńskiego języka literackiego (SSKJ) trwała od roku 1992 do 1994. Pierwsze cztery tomy słownika, wydane w tradycyjny sposób, zostały zeskanowane, zapisane w postaci tekstowej dzięki wykorzystaniu oprogramowania do automatycznego rozpoznawania znaków (OCR), a następnie ręcznie zweryfikowane i uzupełnione, zaś piąty tom był już przed publikacją opracowywany komputerowo (Hajnšek Holz, 1993, s. 421). Pięciotomowy SSKJ wydano następnie w wersji elektronicznej: w roku 1997 na dyskietkach i w roku 1998 na płycie CD-ROM (Ostromęcka-Frączak, 2007, s. 105). W roku 2000 użytkownicy uzyskali dostęp do SSKJ jako słownika internetowego w ramach portalu Slovarske in besedilne zbirke, zaś w roku 2014 również w ramach portalu Fran. Obecnie większość słowników Instytutu Języka Słoweńskiego w wersji cyfrowej na portalu Fran nadal ukazuje się w odstępie kilku lat po publikacji tradycyjnej, mimo że, podobnie jak piąty tom SSKJ, od podstaw opracowywane są komputerowo.
} 
zatem publikowane w wersji tradycyjnej, a następnie udostępniane także w wersji elektronicznej. Dodatkowo SSSS powstał w głównej mierze na podstawie automatycznych procesów generowania synonimów z baz i korpusów językowych i w takiej wersji został udostępniony użytkownikom.

\section{O Słowniku wyrazów bliskoznacznych współczesnego języka słoweńskiego (SSSS)}

Obecnie dostępna wersja słownika zawiera 105473 haseł i 368117 wyrazów bliskoznacznych, co czyni SSSS największym bezpłatnym i automatycznie generowanym zbiorem synonimów języka słoweńskiego. Od innych tego typu publikacji i projektów odróżnia go to, że czerpie $z$ wielu baz danych oraz oferuje możliwość porównania użycia różnych synonimów dzięki odnośnikom do danych w korpusie współczesnego języka słoweńskiego Gigafida. Cała baza jest dostępna bezpłatnie w repozytorium CLARIN.SI (Krek i in., 2018) na licencji Creative Commons: Uznanie autorstwa - Na tych samych warunkach 4.0 Międzynarodowa (CC BY-SA 4.0) (Arhar Holdt i in., 2018, s. 402). Obecnie użytkownicy korzystają z wersji 1.0, na rok 2021 planowane jest udostępnienie zaktualizowanej wersji 2.0.

Synonimy na stronie głównej każdego hasła przypisane są do jednej z trzech grup. Te, które zostały wygenerowane automatycznie, przypisane są do jednej z dwóch pierwszych grup: równoznacznych (słń.jedrni, ang. core) lub bliskoznacznych (słń. bližnji, ang. near), a w obrębie każdej z nich użytkownicy mogą je posortować według czterech kryteriów: rankingu (pokrewieństwa znaczeniowego słów wyliczonego automatycznie), kolejności alfabetycznej, długości wyrazów lub ocen użytkowników (Krek i in., 2017, s. 104). Trzecią grupę stanowią propozycje dodane przez użytkowników.

\section{Tworzenie słownika}

Podstawą bazy SSSS są dane z dwóch głównych źródeł językowych: Wielkiego słownika angielsko-słoweńskiego Oxford-DZS (słń. Veliki angleško-slovenski slovar Oxford-DZS) oraz korpusu Gigafida. Oba zawierają materiały językowe, które powstały po roku $1991^{6}$, dają zatem obraz współczesnego języka słoweńskiego. Wielki słownik angielsko-słoweński

\footnotetext{
${ }^{6}$ Rok ogłoszenia przez Słowenię niepodległości. Data ta wyznacza szereg zmian w systemie politycznym i ekonomicznym kraju, co (głównie poprzez publicystykę) odzwierciedla się także w zmianach, jakie po roku 1991 zaszły w języku słoweńskim (Krek i in., 2017, s. 94).
} 
Oxford-DZS jest przeznaczony w głównej mierze dla rodzimym użytkownikom języka słoweńskiego, dlatego też zawiera nieco więcej ekwiwalentów tłumaczeniowych niż zazwyczaj, a organizacja znaczeń jest dostosowana do potrzeb przekładu, co oznacza, że wszystkie znaczenia generujące takie same ekwiwalenty tłumaczeniowe są ze sobą połączone. Słownik oferuje wyczerpującą listę ekwiwalentów semantycznych i stylistycznych, polegając na zdolności rodzimych użytkowników języka do rozróżniania niuansów znaczeniowych. Synonimy równoznaczne w słowniku rozdzielone są przecinkiem, a wyrazy wymienne tylko w niektórych kontekstach rozdzielono średnikiem, co przy redagowaniu SSSS umożliwiło pogrupowanie pozyskanych synonimów na równoznaczne i bliskoznaczne.

Drugim źródłem danych, głównie dzięki zastosowaniu modułu tezaurusa w programie Sketch Engine, jest udostępniony w roku 2012 referencyjny korpus Gigafida, który zawiera ponad miliard wyrazów z nieco ponad 40 tysięcy tekstów. Program Sketch Engine jest narzędziem służącym do zautomatyzowanego przeszukiwania i analizowania korpusów językowych zawierających autentyczne teksty, które pozwala na określenie zjawisk typowych i nietypowych dla danego języka, w tym także ułatwia wyszukiwanie synonimów. Gigafida to korpus oportunistyczny (czyli zawierający teksty odpowiadające różnym gatunkom i stylom, którego struktura jest przypadkowa, gdyż niektóre teksty występują w nadmiarze, inne zaś w niedomiarze) będący zaktualizowaną i rozbudowaną wersją korpusów FIDA oraz FidaPLUS (z opracowań słoweńskich por. Logar Berginc \& Erjavec, 2012; Logar Berginc i in., 2012; z opracowań polskich, nieobejmujących jednak współczesnego korpusu Gigafida, por. Sewastianowicz, 2014). Powiązania synonimów wygenerowanych z dwóch podstawowych źródeł zostały dodatkowo zweryfikowane przy pomocy drugiego wydania Słownika słoweńskiego języka literackiego $\left(S S K J^{2}\right)$, dostępnego w wersji cyfrowej w ramach portalu Fran. Następnie wykorzystano algorytm Personal PageRank oraz zrównoważone grafy współwystępowania. Dzięki zastosowaniu algorytmu możliwe stało się obliczenie adekwatności i istotności powiązań synonimów. Wyliczenia stały się podstawą do stworzenia grafów współwystępowania, te zaś umożliwiły określenie siatki podstawowych haseł i ich synonimów. Następnie synonimy automatycznie rozdzielono na podgrupy i uszeregowano je według pokrewieństwa znaczeniowego z hasłem oraz według częstotliwości występowania w tekstach (na temat szczegółowej metodologii grupowania synonimów oraz opisu procesu zautomatyzowanego pozyskiwania danych od strony technicznej zob. Krek i in., 2017). 


\section{Nowy typ słownika - słownik reagujacy}

Publikacja SSSS dała początek nowemu typowi słownika - słownikowi reagujacemu (słń. odzivni slovar), który reaguje czy też odpowiada na zachodzące w języku zmiany, gdyż nowoczesna metodologia i wykorzystanie procesów automatyzacji umożliwia ich szybsze rozpoznawanie i uwzględnianie w słowniku. Z drugiej strony słownik reaguje także na nowe potrzeby użytkowników, czy też, szerzej, całej wspólnoty językowej, dając możliwość szybszego i łatwiejszego wzbogacania słownika o jej wiedzę i opinie. Dla słowników tego typu charakterystyczne jest to, że proces ich tworzenia jest otwarty i odbywa się przy współpracy wspólnoty użytkowników. Ważnym elementem słownika reagującego jest także przystosowany interfejs, jednoznacznie określający, na którym stopniu językoznawczych procesów weryfikacyjnych znajduje się obecnie dane hasło, jednocześnie oferując informacje o pochodzeniu danych (źródła językowe lub propozycje użytkowników).

Charakterystyczne jest także to, że baza powstaje z wykorzystaniem nowych technik automatyzacji, co umożliwia udostępnienie użytkownikom większej liczby relewantnych, ale jeszcze niezweryfikowanych (zawierających tzw. szumy, czyli dane niekoniecznie poprawne, adekwatne i relewantne) danych językowych. Kluczowy jest także fakt, że baza jest dostępna bezpłatnie i bez ograniczeń, jednocześnie uwzględniając możliwość i przewidując metody współpracy całej wspólnoty językowej, co przyspiesza proces tworzenia ulepszonej i wyczyszczonej bazy danych. $Z$ tego też wynika podstawowa cecha słownika reagującego - redakcja słownika nigdy nie jest procesem, który może się zakończyć, a informacje o i w hasłach mogą ulegać zmianom wraz ze zmianami realiów językowych (więcej na ten temat Arhar Holdt i in., 2018, s. 404; Čibej \& Arhar Holdt, 2019, ss. 339-340).

\section{Użytkownicy w procesie tworzenia bazy danych słownika (crowdsourcing)}

Jedną z innowacji w słoweńskiej leksykografii jest dopuszczenie użytkowników słownika do jego współtworzenia. Nie jest to jednak zjawisko nowe w leksykografii globalnej. Wystarczy przywołać historię dziewiętnastowiecznego crowdsourcingu ${ }^{7}$, zastosowanego na szeroką skalę przy tworzeniu Oxford English Dictionary (OED). Po opublikowaniu w roku 1857 projektu nowoczesnego

${ }^{7}$ Choć wtedy termin ten oczywiście jeszcze nie funkcjonował. Pojęcie crowdsourcing zostało po raz pierwszy użyte i zdefinio-
wane przez Jeffa Howe'a w artykule z czerwca 2006 roku pt. Rise of crowdsourcing dla magazynu Wired (Howe, 2008, s. 6). 
słownika języka angielskiego (New English Dictionary on Historical Principles) po Wielkiej Brytanii, USA i koloniach brytyjskich rozesłano apele z prośbą o zbieranie, przygotowywanie i przesyłanie do londyńskiego Towarzystwa Filologicznego (Philological Society) fiszek sporządzonych w ustalonym wcześniej formacie, na których ochotnicy mieli wynotowywać przykłady użycia różnych słów z literatury pięknej, fachowej oraz prasy, a które stały się następnie podstawowymi materiałami wykorzystanymi podczas redagowania słownika (Thier, 2014, s. 63).

Role i/lub funkcje użytkowników czy też typy współpracy z nimi przy redagowaniu słowników dokładniej przedstawili np. Andrea Abel i Chistian Meyer (por. Abel \& Meyer, 2013). Inne badania pokazały także, że głównymi oczekiwaniami i potrzebami użytkowników słowników w dobie cyfryzacji są przede wszystkim dostęp do wysokiej jakości aktualnych danych językowych oraz możliwość wyrażania swojej opinii i przekazywania propozycji udoskonaleń (Müller-Spitzer \& Koplenig, 2014, ss. 148, 156-159). Mimo to udział użytkowników słoweńskich przy współtworzeniu słowników elektronicznych wcześniej nie był integralną częścią koncepcji słownika (Čibej, 2019, s. 2). Automatyczne wygenerowanie słownika z dostępnych źródeł językowych nigdy nie było celem końcowym przy redagowaniu SSSS (Krek i in., 2017, s. 104), dlatego tak ważne stało się umożliwienie użytkownikom udziału w procesie jego powstawania.

Jak zauważają słoweńscy leksykografowie Jaka Čibej, Darja Fišer i lztok Kosem, zaangażowany w redagowanie słownika "tłum" wcale nie musi składać się z ekspertów, gdyż nawet grupa osób niebędących ekspertami w danej dziedzinie jest wystarczająco uzdolniona, kreatywna i produktywna, aby rozwiązać skomplikowane zadania, a wraz z rozpowszechnieniem Internetu korzystanie z wiedzy „tłumu” stało się dużo prostsze, szybsze, wydajniejsze i korzystniejsze finansowo (Čibej i in., 2015, s. 70). Takie rozwiązanie wzbudziło jednak kilka krytycznych głosów, które przywołuję i omawiam w dalszych częściach artykułu.

W ciągu ostatnich piętnastu lat crowdsourcing był z powodzeniem stosowany w pracach językoznawczych i leksykograficznych, zatem może być stosowany także na większą skalę, jednak nie jako faza główna lub końcowa procesu tworzenia słowników, ale raczej jako metoda przetwarzania i/lub czyszczenia danych (por. Čibej i in., 2015, s. 71). Nowy podział pracy zakłada zatem wykorzystanie wiedzy osób niebędących leksykografami do wykonywania mniej złożonych czy też bardziej rutynowych zadań, a pracy ekspertów do opracowywania zagadnień trudniejszych, bardziej analitycznych, co pozwala na przyspieszenie prac redakcyjnych nad słownikiem (Kosem i in., 2013, s. 46). Dodatkowo monitorowanie zaangażowania użytkowników zakłada odnotowywanie i uwzględnianie ich wkładu już od samego początku prac, co gwarantuje reakcję słownika reagującego, która jest jego cechą fundamentalną (Čibej, 2019, s. 2). 
Spośród oferowanych przez SSSS aktywności i sposobów angażowania użytkowników wymienić należy ewaluację czy też ocenianie dostępnych synonimów, bezpośrednie dodawanie własnych propozycji, otwartą dyskusję o dostępnych rozwiązaniach oraz import ewentualnych istniejących materiałów użytkowników do bazy danych słownika (Arhar Holdt i in., 2018, s. 405). Dodawane przez użytkowników propozycje synonimów są zapisywane w bazie słownika oraz wyświetlane w części przeznaczonej na proponowane synonimy. Użytkownicy mogą także oceniać pozytywnie (+1) lub negatywnie (-1) wszystkie dostępne synonimy pod kątem adekwatności. Oceny te zapisywane są w bazie, jednocześnie będąc także częścią interfejsu, co umożliwia sortowanie danych od najwyżej do najniżej ocenionych. Do listopada 2019 dodano łącznie 34210 ocen pozytywnych i 5509 negatywnych oraz 23140 propozycji synonimów, przy czym najczęściej dodawano synonimy nienacechowane stylistycznie i współcześnie używane, np. atribut - prednost (pol. atrybut - zaleta), alarm - opomnik (pol. alarm - przypomnienie), arhivirati - shraniti (pol. archiwizować - zapisać) (Čibej, 2019, s. 14). Do maja 2020 liczba dodanych przez użytkowników propozycji synonimów wzrosła do 26683 , zestawienie nie obejmuje natomiast liczby dodanych ocen (Arhar Holdt \& Čibej, 2020, s. 6). Przygotowano także dane statystyczne z czasu wprowadzonego w Słowenii stanu epidemii COVID-19 (Center za jezikovne vire in tehnologije, 2020b), który ogłoszono 13 marca i odwołano 31 maja. W tym czasie pojawiło się łącznie 7862 ocen synonimów, z czego 5452 stanowiły oceny pozytywne, a 2410 oceny negatywne. Użytkownicy w tym czasie dodali 2940 nowych synonimów, w tym tematycznie związane z epidemią, np. razkuževati - dezinfecirati (pol.odkażać - dezynfekować), virus - patogen (pol. wirus - patogen) itp.

Jak zauważają pracownicy CJVT, bez odpowiedniej motywacji użytkowników nie można by oczekiwać ich wkładu w uzupełnianie słownika (Holdt i in., 2018, s. 405), zatem interfejs SSSS oferuje także rozwiązania ją podnoszące. W obecnie dostępnej wersji są to np. zakładka "Wspólnota" (słń. Skupnost) pełniąca rolę galerii sław, czyli listy najbardziej aktywnych użytkowników dodających najwięcej nowych propozycji, oraz sekcja "Zadania dnia” (słń. Naloge dneva), czyli losowa lista haseł, które nie zostały jeszcze ocenione przez użytkowników. Dodatkowo utworzono także stronę internetową, na której znajdują się materiały promujące słownik (Center za jezikovne vire in tehnologije, b.d.-b) oraz profil na portalu Facebook (Center za jezikovne vire in tehnologije, 2020a), który ma za zadanie promować nie tylko SSSS, ale także inne projekty CJVT. Użytkownicy mogą skorzystać również z możliwości zamówienia newslettera. Promocja obejmuje także wydarzenia przybliżające słownik nowym potencjalnym użytkownikom, publikację powiązanych z nim materiałów, w tym raportów czy artykułów 
naukowych, oraz serię podcastów, w których goście dokładniej opisują SSSS. Centrum Zasobów i Technologii Językowych prowadzi także swój kanał w serwisie YouTube (Center za jezikovne vire in tehnologije, 2019), gdzie dostępne są nagrania ze spotkań promujących SSSS oraz inne zasoby językowe, za które CJVT odpowiada, oraz wideopomoc, czyli filmiki instruktażowe przybliżające użytkownikom wszystkie dostępne funkcje słownika.

\section{Krytyka słownika}

Głównym zarzutem pojawiającym się w kontekście SSSS jest to, że wygenerowane automatycznie dane udostępniane są użytkownikom przed weryfikacją leksykograficzną, w związku z tym nie są wiarygodne. Jak twierdzą badacze (zob. Arhar Holdt i in., 2018, s. 402; Krek i in., 2017, ss. 101-103), automatyczne pozyskiwanie i grupowanie danych nigdy nie jest w stu procentach precyzyjne, testy pokazują jednak, że metoda automatycznego wyłuskiwania mimo wszystko daje wystarczająco wiarygodne i korzystne dla użytkowników słownika rezultaty. Pozyskane automatycznie dane poddane zostały ocenie językoznawczej, synonimy dla poszczególnych haseł oceniono jako adekwatne, akceptowalne lub nieodpowiednie, gdzie ostatnia grupa stanowiła procentowo najmniejszą część z wygenerowanych automatycznie synonimów. W tym miejscu należy jednak zaznaczyć, że tego rodzaju opiniowanie nie jest wcale łatwym i jednoznacznym zadaniem także dla ekspertów, gdyż koncepcja synonimii (którą każdy z badaczy może interpretować inaczej, zob. Snoj, 2019, ss. 13-41; Vidovič Muha, 2013, ss. 172-183; Zorman, 2000, ss. 20-48) jest bardzo szeroka i nierozerwalnie powiązana z kontekstem oraz okolicznościami użycia danego słowa. Nie istnieje jedna uniwersalna definicja synonimu, każdy badacz (a tak naprawdę każdy człowiek) może do tego problemu podchodzić inaczej. Dwa słowa, które przez jednych zostaną uznane za synonimy, dla innych mogą nimi nie być lub nie być nimi tylko w konkretnych kontekstach, rodzajach tekstów, sytuacjach itp. Stąd tak trudnym z leksykograficznego punktu widzenia zadaniem jest decydowanie, które słowa czy wyrażenia powinny się znaleźć w grupie synonimów, a które nie, zwłaszcza jeśli słownik z różnych przyczyn nie podaje przykładów użycia interesującego nas hasła.

Innym zarzutem jest dopuszczenie do (współ)tworzenia słownika jego użytkowników. Abstrahując od możliwości oceny adekwatności proponowanych wyrazów bliskoznacznych, wiele wątpliwości w słoweńskim środowisku leksykograficznym budzi możliwość dodawania przez użytkowników nowych synonimów do istniejących już haseł. Rejestracja nie jest wymagana, należy podać jedynie wybraną przez siebie nazwę użytkownika, a proponowane synonimy widoczne są natychmiast (Arhar Holdt i in., 2018, s. 406). Rodzi to pytania głównie o rozwiązywanie kwestii 
złośliwych wpisów, które są jednak niezwykle rzadkie (ok. 6\% wszystkich dodanych wpisów, por. Arhar Holdt \& Čibej, 2020, s. 6). Kontrola wpisów leży także w gestii pozostałych użytkowników, którzy mogą oddać głos negatywny. Statystyki z listopada 2019 roku pokazują, że użytkownicy (445 różnych nazw użytkowników) od momentu udostępnienia słownika dodali 23140 propozycji synonimów (Čibej, 2019, s. 14), do maja 2020 liczba odnotowanych nazw użytkowników wzrosła do 597, liczba dodanych propozycji zaś do 26683 (Arhar Holdt \& Čibej, 2020, s. 6). Analiza zrównoważonego wzorca 1662 synonimów (nie więcej niż 10 propozycji na użytkownika) pokazała, że większość propozycji jest konstruktywnych - oprócz haseł neutralnych (1 175 wpisów) użytkownicy dodawali do słownika propozycje słów występujących w dialektach lub w mowie potocznej (218 wpisów) oraz w slangu (67 wpisów). Tylko 110 wpisów uznano za nieadekwatne, co nie oznacza, że są one jednocześnie niekonstruktywne. Procentowo propozycje rozkładały się następująco: ponad 70\% wpisów konstruktywnych i nienacechowanych stylistycznie, ponad $20 \%$ wpisów konstruktywnych i nacechowanych stylistycznie oraz nieco ponad 6\% wpisów niekonstruktywnych, np. lapsusów czy złośliwych wpisów, a analizie poddano jak dotąd tylko wpisy użytkowników, których odnotowano do grudnia 2019 (Arhar Holdt \& Čibej, 2020, s.6). Można zatem uznać, że zarzuty dotyczące złośliwości wpisów nie są tak poważnym problemem, jak sugerują to zwolennicy tradycyjnych metod tworzenia słowników, gdzie wszystkie hasła przed upublicznieniem są weryfikowane przez leksykografów.

Inną często poruszaną kwestią jest także zdolność „zwykłych”, czyli nieposiadających językoznawczego czy wręcz leksykograficznego wykształcenia, użytkowników języka do współtworzenia słownika. W myśl słoweńskiego porzekadła, że więcej głów więcej wie (słń. več glav več ve) oraz opisanej już zasady crowdsourcingu uznano, że wszyscy użytkownicy języka słoweńskiego ${ }^{8}$, niezależnie od wykształcenia, są w stanie rzetelnie rozbudowywać i uzupełniać bazę danych, na co wskazuje sam tytuł projektu, w ramach którego słownik był w latach 2018 i 2019 finansowany - Słownik wyrazów bliskoznacznych współczesnego języka słoweńskiego: od wspólnoty dla wspólnoty (słń. Slovar sopomenk sodobne slovenščine: od skupnosti za skupnost). Badania przeprowadzone w roku 2008 z użyciem narzędzia Amazon Mechanical Turk (AMT) pokazują także, że zwłaszcza w kontekście oceny podobieństwa dwóch słów czy też adekwatności proponowanych synonimów crowdsourcing jest wyjątkowo skuteczny, a odpowiedzi oceniających niebędących ekspertami prawie nie odbiegają od złotego standardu, czyli odpowiedzi ustalonych przez ekspertów (Snow i in., 2008, ss. 257-258).

\footnotetext{
${ }^{8} \mathrm{~W}$ tym także osoby posługujące się językiem słoweńskim jako drugim i/lub obcym, które są jedną z grup docelowych wziętych pod uwagę przy tworzeniu słownika.
} 


\section{Atuty słownika}

Mimo omawianych wyżej głównych zarzutów i wątpliwości nie sposób nie zauważyć także zalet słownika. Innowacyjne metody leksykografii komputerowej oraz komputerowo wspomagane pozyskiwanie i przygotowywanie danych jest zdecydowanie mniejszym obciążeniem finansowym i rozwiązaniem mniej pracochłonnym niż ręczne zbieranie, opisywanie i opracowywanie materiałów. Jest też niezaprzeczalnie szybsze, gdyż co prawda „komputery nie są w stanie czytać i rozumieć tak jak ludzie, mają jednak zdolność przetwarzania dużych ilości danych w sposób szybki i zestandaryzowany" (Collins i in., 2015, s. 12). Czas przeznaczony na zebranie i publikację rezultatów jest niewątpliwym atutem słownika, gdyż umożliwia użytkownikom szybszy dostęp do interesujących ich danych, co w połączeniu z digitalnymi zasobami językowymi umożliwia szybsze wprowadzanie, rozbudowywanie i aktualizowanie haseł, czyniąc ze słownika dynamiczną bazę danych.

Aby w pełni zrozumieć synonimię, koniecznie należy wziąć pod uwagę kontekst, dlatego też dużo uwagi poświęcono powiązaniom haseł z danymi z korpusów. Oprócz tego dzięki metodom automatycznego rozpoznawania adekwatnych wzorców w słowniku znaleźć można także przykłady użycia danego hasła. Przykłady użycia przypisane są do większości haseł, przy wszystkich dodatkowo dostępny jest link do korpusu Gigafida, co umożliwia dalsze badania nad współczesnym użytkowaniem języka. Z Wielkiego słownika angielsko-słoweńskiego Oxford-DZS przeniesiono także kwalifikatory objaśniające kontekst użycia poszczególnych słów. Także opisane wyżej reagowanie na zmiany językowe i potrzeby użytkowników oraz wykorzystanie ich wiedzy i motywacji poprzez współudział w tworzeniu słownika na zasadzie crowdsourcingu jest jedną z jego niewątpliwych zalet.

\section{Planowana aktualizacja słownika}

Pod koniec roku 2020 planowana była aktualizacja SSSS do wersji 2.0, jednak termin ten może uległ zmianie, gdyż epidemia COVID-19 znacząco spowolniła prace nad planowaną aktualizacją, która ukaże się dopiero w roku 2021. Aktualizacja przyniesie poszerzenie bazy danych o przykłady użycia ze zaktualizowanego wcześniej korpusu Gigafida - wersja Sopomenke 2.0 zawierać będzie odnośniki do Gigafidy 2.0. Bardzo duża liczba haseł, które znaleźć można w słowniku (zarówno wygenerowanych automatycznie, jak i dodanych przez użytkowników), przejdzie dodatkową ewaluację pod kątem adekwatności. Pod uwagę wzięta zostanie także liczba pozytywnych i nega- 
tywnych ocen użytkowników słownika, a dodatkowej oceny dokonają osoby z wykształceniem językoznawczym (w tym studenci Uniwersytetu w Lublanie, por. Čibej \& Arhar Holdt, 2019, s. 343). Zaproponowane przez użytkowników hasła z dużą liczbą ocen pozyty wnych zostaną przesunięte do pierwszej sekcji wyświetlanych synonimów, zatem do danych zweryfikowanych, niemalże stuprocentowo pewnych. W odpowiedzi na potrzeby użytkowników rozpocznie się również dodawanie kwalifikatorów do poszczególnych haseł (Arhar Holdt i in., 2018, s. 407), początkowo szczególnie hasłom „problematycznym”, np. synonimom, które w pewnych kontekstach mogą być odbierane jako obraźliwe (typu ženska-baba, pol. kobieta - baba) (Čibej, 2019, ss. 4-5). Brane pod uwagę jest także udostępnienie użytkownikom możliwości dodawania nowych, brakujących haseł głównych, a nie tylko kolejnych synonimów do haseł już istniejących (Arhar Holdt i in., 2018, s. 407) oraz przypisanie poszczególnych haseł do określonej części mowy, co pozwoli utworzyć osobne hasła dla homonimów (Arhar Holdt \& Čibej, 2020, s. 7).

\section{Zakończenie}

Jak zaznaczyłam powyżej, redagowanie słownika jest niekończącym się procesem. Przed rewolucją cyfrową rozwiązaniem umożliwiającym reagowanie na zachodzące w języku zmiany była publikacja suplementów do opracowywanych latami słowników. Większa dostępność i lepsza jakość zasobów cyfrowych umożliwiają szybsze zbieranie i publikację danych oraz łatwiejsze reagowanie na zmiany - rolę suplementu w słownikach internetowych pełni aktualizacja. Oprócz usprawnienia prac redakcyjnych automatyzacja procesów leksykograficznych obniża także koszty przygotowywania słowników. Mimo swoich niewątpliwych zalet wymaga jednak ciągłego udoskonalania metodologii i ręcznych procesów weryfikacyjnych, w które, jak opisałam powyżej, z powodzeniem można zaangażować samych użytkowników słownika, gdyż ich wiedza językowa często jest odmienna, jednak niekoniecznie gorsza od wiedzy ekspertów.

Przedstawiony Słownik wyrazów bliskoznacznych współczesnego języka słoweńskiego jest przykładem tego, jak z powodzeniem można korzystać z rozwoju technologii, aby stworzyć dobrej jakości słownik internetowy, jednocześnie, miejmy nadzieję, wyznaczający nowy trend w leksykografii komputerowej - słownik reagujący, który wydaje się być odpowiedzią na większość oczekiwań użytkowników słowników elektronicznych, które badali zarówno światowi, jak i słoweńscy eksperci z dziedziny leksykografii (zob. np. Abel \& Meyer, 2013; Arhar Holdt, 2018). Metodologia pozyskiwania danych jest ogólna, może zatem zostać wykorzystana 
w podobnych projektach dla innych słowników i innych języków. SSSS jest też dowodem na to, że w proces redagowania słownika z powodzeniem można zaangażować także samych jego użytkowników, co w przypadku języka słoweńskiego, charakteryzującego się ogromnym zróżnicowaniem dialektalnym i regionalnym, ma dodatkowo duże znaczenie. SSSS w swoim obecnym kształcie wymaga jednak dalszych procesów weryfikacji wiarygodności i adekwatności synonimów, czyszczenia bazy danych, udoskonalania dostępnych już rozwiązań oraz wprowadzania nowych, co przynajmniej częściowo przyniesie planowana aktualizacja.

\section{Bibliografia}

Abel, A., \& Meyer, C. M. (2013). The dynamics outside the paper: User contributions to online dictionaries. W I. Kosem, J. Kallas, P. Gantar, S. Krek, M. Langemets, \& M. Tuulik (Red.), Electronic lexicography in the 21st century: Thinking outside the paper. Proceedings of the eLex 2013 conference, 17-19 October 2013, Tallinn, Estonia (ss. 179-194). Trojina, Institute for Applied Slovene Studies. http://eki.ee/elex2013/proceedings/eLex2013_13_Abel+Meyer.pdf

Arhar Holdt, Š. (2018). Odnos jezikovnih uporabnikov do splošnih enojezičnih slovarjev: Slovenski vidik. Slovenščina 2.0, 6(1), 1-36. https://doi.org/10.4312/slo2.0.2018.1.1-36

Arhar Holdt, Š., \& Čibej, J. (2020). Rezultati projekta "Slovar sopomenk sodobne slovenščine: Od skupnosti za skupnost". W D. Fišer \& T. Erjavec (Red.), Zbornik konference Jezikovne tehnologije in digitalna humanistika, 24. - 25. september 2020, Ljubljana, Slovenija (ss. 3-9). Inštitut za novejšo zgodovino. http://nl.ijs.si/jtdh20/pdf/JT-DH_2020_Arhar-Holdt-et-al_Rezultati -projekta_Slovar-sopomenk-sodobne-slovenscine.pdf

Arhar Holdt, Š., Čibej, J., Dobrovoljc, K., Gantar, P., Gorjanc, V., Klemenc, B., Kosem, I., Laskowski, C., \& Robnik-Šikonja, M. (2018). Thesaurus of modern Slovene: By the community for the community. W J. Čibej, V. Gorjanc, I. Kosem, \& S. Krek (Red.), Proceedings of the XVIII EURALEX International Congress, Lexicography in Global Contexts, 17-21 July 2018, Ljubljana (ss. 401-410). Znanstvena založba Filozofske fakultete. https://euralex.org/wp-content/themes/euralex /proceedings/Euralex\%202018/118-4-2991-1-10-20180820.pdf

Center za jezikovne vire in tehnologije. (2019). Strona domowa [Kanał YouTube]. YouTube. Pobrano 6 listopada 2020, z www.youtube.com/channel/UCwJ7d5M4Mhn-UGOU3tZGOxQ/featured

Center za jezikovne vire in tehnologije. (2020a). Strona domowa [Strona Facebook]. Facebook. Pobrano 6 listopada 2020, z www.facebook.com/centerzajezikovnevireintehnologije/

Center za jezikovne vire in tehnologije. (2020b, lipiec 14). Slovar sopomenk sodobne slovenščine med epidemijo. https://www.cjvt.si/blog/sopomenke-med-epidemijo/

Center za jezikovne vire in tehnologije. (b.d.-a). CJVT Sopomenke: About. https://viri.cjvt.si /sopomenke/eng/about

Center za jezikovne vire in tehnologije. (b.d.-b). Promocija Sopomenk. https://www.cjvt.si /promocija-sopomenk/ 
Čibej, J. (2019). Končno poročilo o spremljanju uporabniških odzivov, mnenj in načinov uporabniškega vključevanja: Projekt Slovar sopomenk sodobne slovenččine: Od skupnosti za skupnost. Center za jezikovne vire in tehnologije. https://www.cjvt.si/promocija-sopomenk/wp-content /uploads/sites/24/2019/11/koncno_porocilo_o_spremljanju_uporabniskih_odzivov_mnenj _in_nacinov_uporabniskega_vkljucevanja.pdf

Čibej, J., \& Arhar Holdt, Š. (2019). Repel the syntruders! A crowdsourcing cleanup of the Thesaurus of Modern Slovene. W I. Kosem, T. Zingano Kuhn, M. Correia, J. P. Ferreira, M. Jansen, I. Pereira, J. Kallas, M. Jakubíček, S. Krek, \& C. Tiberius (Red.), Electronic lexicography in the 21st century: Smart lexicography. Proceedings of the eLex 2019 conference, 1-3 October 2019, Sintra, Portugal (ss. 338-356). Lexical Computing CZ s.r.o. https://elex.link/elex2019/wp-content /uploads/2019/09/eLex_2019_19.pdf

Čibej, J., Fišer, D., \& Kosem, I. (2015). The role of crowdsourcing in lexicography. W I. Kosem, M. Jakubíček, J. Kallas, \& S. Krek (Red.), Electronic lexicography in the 21st century: Linking lexical data in the digital age. Proceedings of eLex 2015 Conference, 11-13 August 2015, Herstmonceux Castle, United Kingdom (ss. 70-83). Trojina, Institute for Applied Slovene Studies. https://elex.link /elex2015/proceedings/eLex_2015_05_Cibej+Fiser+Kosem.pdf

Collins, S., Harrower, N., Haug, D., Immenhauser, B., Lauer, G., Orlandi, T., Romary, L., \& WandlVogt, E. (2015). Going digital: Creating change in the humanities. All European Academies (ALLEA). https://www.allea.org/wp-content/uploads/2015/07/Going-Digital_digital-version.pdf

Hajnšek Holz, M. (1993). Leksikografski problemi prenosa knjižne oblike Slovarja slovenskega knjižnega jezika v računalniško. W I. Štrukelj (Red.), Jezik tako in drugače (ss. 420-432). Društvo za uporabno jezikoslovje Slovenije.

Howe, J. (2008). Crowdsourcing: Why the power of the crowd is driving the future of business. Crown Publishing Group.

Inštitut za slovenski jezik. (2018). Slovarske in besedilne zbirke. http://bos.zrc-sazu.si/

Inštitut za slovenski jezik. (2020). Fran: Slovarji Inštituta za slovenski jezik Frana Ramovša ZRC SAZU. http://www.fran.si/

Kosem, I., Gantar, P., \& Krek, S. (2013). Automation of lexicographic work: An opportunity for both lexicographers and crowd-sourcing. W I. Kosem, J. Kallas, P. Gantar, S. Krek, M. Langemets, \& M. Tuulik (Red.), Electronic lexicography in the 21st century: Thinking outside the paper. Proceedings of the eLex 2013 conference, 17-19 October 2013 (ss. 32-48). Trojina, Institute for Applied Slovene Studies. http://eki.ee/elex2013/proceedings/eLex2013_03_Kosem+Gantar+Krek.pdf

Krek, S., Laskowski, C., \& Robnik-Šikonja, M. (2017). From translation equivalents to synonyms: Creation of a Slovene thesaurus using word co-occurrence network analysis. W I. Kosem, C. Tiberius, M. Jakubíček, J. Kallas, S. Krek, \& V. Baisa (Red.), Electronic lexicography in the 21st century. Proceedings of eLex 2017 conference: Lexicography from Scratch. Leiden, the Netherlands, 19-21 September 2017 (ss. 93-109). Lexical Computing CZ s.r.o. https://elex.link/elex2017 /wp-content/uploads/2017/09/paper05.pdf

Krek, S., Laskowski, C., Robnik-Šikonja, M., Kosem, I., Arhar Holdt, Š., Gantar, P., Čibej, J., Gorjanc, V., Klemenc, B., \& Dobrovoljc, K. (2018). Thesaurus of Modern Slovene 1.0. Slovenian language resource repository CLARIN.SI. http://hdl.handle.net/11356/1166 
Logar Berginc, N., \& Erjavec, T. (2012). Referenčni korpusi slovenskega jezika (cc)Gigafida in (cc)KRES. W T. Erjavec \& J. Žganec Gros (Red.), Zbornik osme konference jezikovne tehnologije, 8-12 oktober 2012, Ljubljana, Slovenija (ss. 57-62). Institut "Jožef Stefan". http://nl.ijs.si/isjt12 /JezikovneTehnologije2012.pdf

Logar Berginc, N., Grčar, M., Brakus, M., Erjavec, T., Arhar Holdt, Š., \& Krek, S. (2012). Korpusi slovenskega jezika Gigafida, KRES, ccGigafida in ccKRES: gradnja, vsebina, uporaba. Trojina, zavod za uporabno slovenistiko.

Müller-Spitzer, C. (2014). Introduction. W C. Müller-Spitzer (Red.), Using online dictionaries (ss. 1-10). de Gruyter. https://doi.org/10.1515/9783110341287.1

Müller-Spitzer, C., \& Koplenig, A. (2014). Online dictionaries: Expectations and demands. W C. Müller-Spitzer (Red.), Using online dictionaries (ss. 143-188). De Gruyter. https://doi.org /10.1515/9783110341287.143

Ostromęcka-Frączak, B. (2007). Historia leksykografii łłoweńskiej. Wydawnictwo Uniwersytetu Łódzkiego. Sewastianowicz, A. (2014). Praktyczny przewodnik po korpusie języka słoweńskiego. W M. Hebal-Jezierska (Red.), Praktyczny przewodnik po korpusach języków słowiańskich (ss. 107-122). Wydział Polonistyki Uniwersytetu Warszawskiego.

Snoj, J. (2019). Leksikalna sinonimija v sinonimnem slovarju slovenskega jezika. Založba ZRC, ZRC SAZU.

Snow, R., O'Connor, B., Jurafsky, D., \& Ng, A. Y. (2008). Cheap and fast: But is it good? Evaluating non-expert annotations for natural language tasks. W Proceedings of the 2008 Conference on Empirical Methods in Natural Language Processing, 25-27 October 2008, Honolulu, Hawaii, USA (ss. 254-263). Omnipress Inc. https://www.aclweb.org/anthology/D08-1027.pdf

Thier, K. (2014). Das Oxford English Dictionary und seine Nutzer. W A. Abel \& A. Klosa (Red.) OPAL - Online publizierte Arbeiten zur Linguistik. Der Nutzerbeitrag im Wörterbuchprozess. 3. Arbeitsbericht des wissenschaftlichen Netzwerks "Internetlexikografie" (ss. 63-70). Institut für Deutsche Sprache. https://pub.ids-mannheim.de/laufend/opal/pdf/opal2014-4.pdf

Vidovič Muha, A. (2013). Slovensko leksikalno pomenoslovje. Znanstvena založba Filozofske fakultete. Zorman, M. (2000). O sinonimiji. Znanstveni inštitut Filozofske fakultete.

\section{Dictionaries in the Age of Digitisation: An Example of the Thesaurus of Modern Slovene (Slovar sopomenk sodobne slovenščine)}

The digital revolution enables publishing dictionaries in a digital version, which significantly facilitates access to them by their users, who are no longer mere recipients of the content: their potential is viewed as useful in (co-)editing dictionaries. These changes also enable the introduction of new solutions to improve editorial work. One case in point is the Thesaurus of Modern Slovene (Slovar sopomenk sodobne slovenšcine) - the first responsive dictionary, 
generated mostly automatically based on available language data, which responds both to language changes as well as to the habits and needs of its users. Their opinions and proposals have become integral part of its concept through crowdsourcing.

\title{
Keywords:
}

Thesaurus of Modern Slovene; responsive dictionary; digital lexicography; crowdsourcing; synonymy; CJVT

\section{Słowniki w dobie digitalizacji na przykładzie Słownika wyrazów bliskoznacznych współczesnego języka słoweńskiego (Slovar sopomenk sodobne slovenščine)}

\begin{abstract}
Rewolucja cyfrowa umożliwia udostępnianie słowników w wersji cyfrowej, co znacząco ułatwia dostęp do nich użytkownikom, którzy nie są już tylko odbiorcami treści, ale dostrzega się także ich potencjał przy (współ)redagowaniu słowników. Dzięki niej możliwe jest także wprowadzanie nowych rozwiązań usprawniających prace redakcyjne. Jednym z przykładów jest słoweński Słownik wyrazów bliskoznacznych współczesnego języka słoweńskiego (Slovar sopomenk sodobne slovenščine) - pierwszy słownik reagujący, wygenerowany w większości automatycznie na podstawie dostępnych danych językowych, który reaguje zarówno na zachodzące w języku zmiany, jak i zwyczaje i potrzeby jego użytkowników, których opinie i propozycje stały się jego integralną częścią dzięki zastosowaniu crowdsourcingu.
\end{abstract}

\section{Słowa kluczowe:}

Słownik wyrazów bliskoznacznych współczesnego języka słoweńskiego; słownik reagujący; leksykografia komputerowa; crowdsourcing; synonimia; CJVT

\section{Citation:}

Gapsa, M. (2020). Słowniki w dobie digitalizacji na przykładzie Słownika wyrazów bliskoznacznych współczesnego języka słoweńskiego (Slovar sopomenk sodobne slovenščine). Adeptus, 2020(16), Article 2227. https://doi.org/10.11649/a.2227

\section{Publication History:}

Received: 2020-01-30; Accepted: 2020-11-12; Published: 2020-12-31 